\title{
Relation of Blood Pressure with Rice Likeness
}

\author{
Muhammad Imran Qadir and Aqdas Tayyaba* \\ Institute of Molecular Biology and Biotechnology, Pakistan \\ *Corresponding author: Aqdas Tayyaba, Institute of Molecular Biology and Biotechnology, Multan, Pakistan
}

\section{ARTICLE INFO}

Received: 慧 February 13, 2019

Published: 慧 February 26, 2019

Citation: Muhammad Imran Q Aqdas T. Relation of Blood Pressure with Rice Likeness. Biomed J Sci \& Tech Res 15(1)-2019. BJSTR. MS.ID.002658.

\begin{abstract}
When heart beat pumps blood around the body to gives the energy. Hypertension principal is a progenitor of choke heart failure, the relations of diastolic, systolic and pulse pressure for heart failure have not been completely illuminated. Increased blood pressure help in identifying hypersensitive patients where high risk for heart failure is present.
\end{abstract}

Keywords: Pulse Rate; Pulse Pressure

\section{Introduction}

Blood pressure is the circulating blood on the walls of blood vessels. This pressure is due to the work done by heart in blood pumping around the circulation. Blood pressure is the pressure in arteries where blood circulate. Blood pressure is terms as the diastolic pressure over systolic pressure and it is in millimeters. Blood pressure show important signs with body temperature, respiration, oxygen saturation and heart rate. Normal blood pressure in a person is 90 millimeters diastolic and 130 millimeters systolic. Blood pressure is affected by peripheral resistance, cardiac output and stiffness of arteries and changing depends on the emotional state, situation, overall health and activity [1-10].

\section{Material and Method}

There were 200 students of BZU that check blood pressure and shows results. The values are significant.

\section{Project Design}

The questionnaire had been prepared to relate the blood pressure with the rice likeness.

\section{Statistical Analysis}

Statistical analysis was performed by using MS excel.

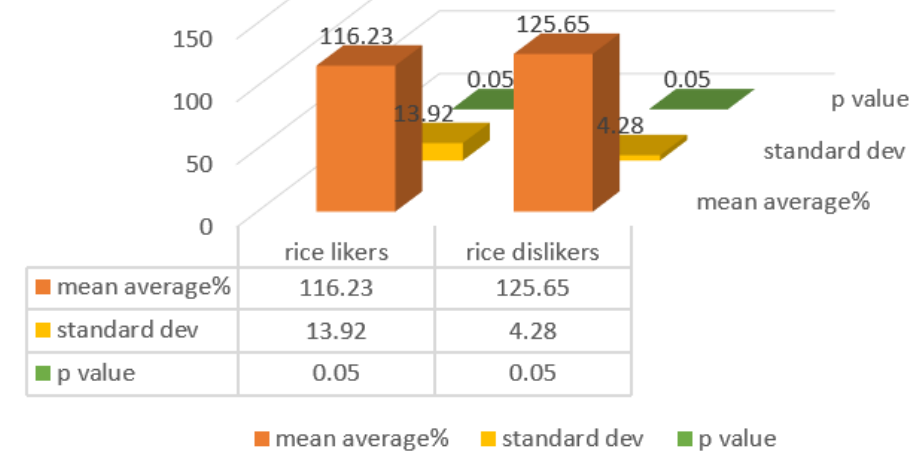

Graph 1: Systolic difference. 


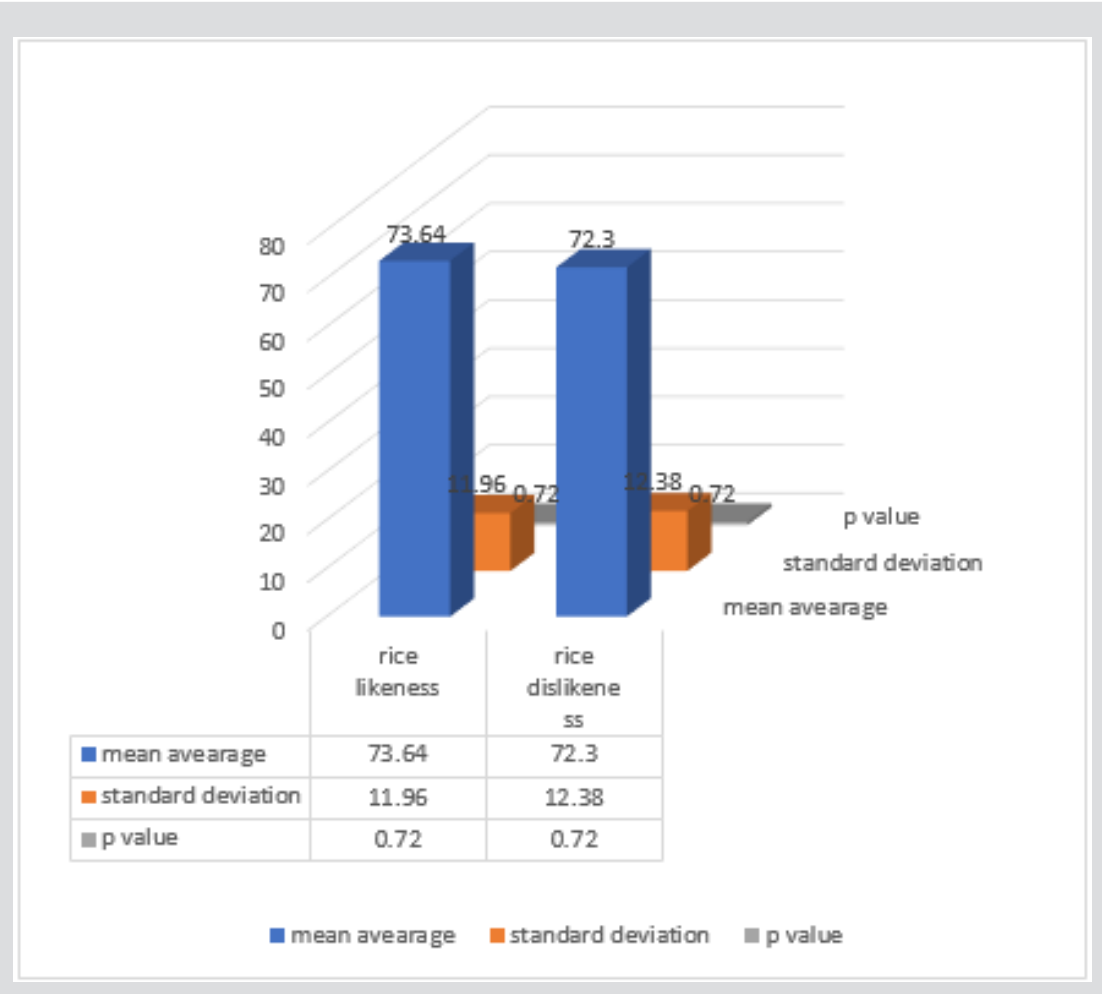

Graph 2: Diastolic difference.

\section{Result and Discussion}

Graph1: systolic difference.

Graph2: diastolic difference.

\section{Conclusion}

It is concluded from the above studies that rice likeness has relation with blood pressure.

\section{References}

1. Qadir MI, Malik SA (2010) Comparison of alterations in red blood cell count and alterations in hemoglobin concentration in patients suffering from rectal carcinoma undergoing 5-fluorouracil and folic acid therapy. Pharmacologyonline Nl 3: 240-243.

2. Qadir MI, Noor A (2018) Anemias. Rare \& Uncommon Diseases. Cambridge Scholars Publishing. Newcastle, England pp. 64967.

3. Qadir MI, Javid A (2018) Awareness about Crohn's Disease in biotechnology students. Glo Adv Res J Med Medical Sci 7(3): 062-064.

\section{ISSN: 2574-1241}

DOI: 10.26717/BJSTR.2019.15.002658

Aqdas Tayyaba. Biomed J Sci \& Tech Res

This work is licensed under Creative Commons Attribution 4.0 License

Submission Link: https://biomedres.us/submit-manuscript.php
4. Qadir MI, Saleem A (2018) Awareness about ischemic heart disease in university biotechnology students. Glo Adv Res J Med Medical Sci 7(3): 059-061.

5. Qadir MI, Ishfaq S (2018) Awareness about hypertension in biology students. Int J Mod Pharma Res, 7(2): 08-10.

6. Qadir MI, Mehwish (2018) Awareness about psoriasis disease. Int J Mod Pharma Res, 7(2): 17-18.

7. Qadir MI, Shahzad R (2018) Awareness about obesity in postgraduate students of biotechnology. Int J Mod Pharma Res 7(2): 14-16.

8. Qadir MI, Rizvi M (2018) Awareness about thalassemia in post graduate students. MOJ Lymphology \& Phlebology 2(1): 14-16.

9. Qadir MI, Ghalia BA (2018) Awareness survey about colorectal cancer in students of M. Phil Biotechnology at Bahauddin Zakariya University, Multan, Pakistan. Nov Appro in Can Study 1(3): NACS.000514.2018.

10. Qadir MI, Saba G (2018) Awareness about intestinal cancer in university student. Nov Appro in Can Study 1(3): NACS.000515.2018.

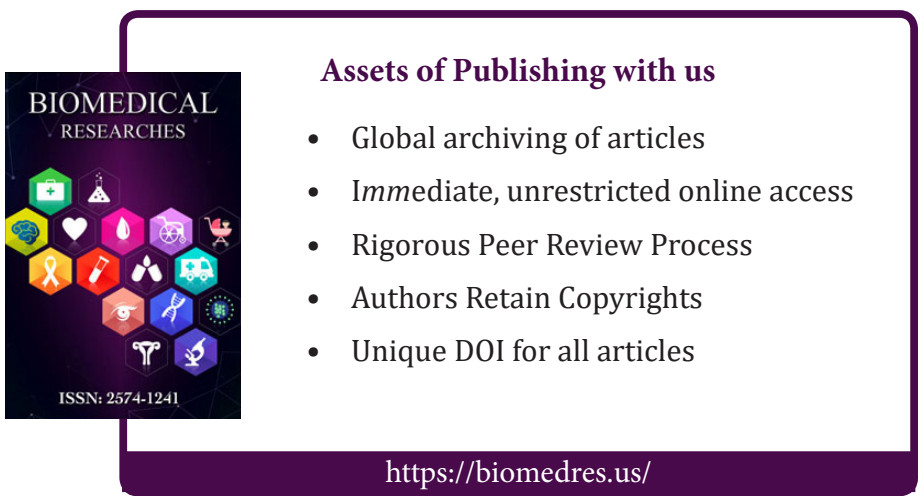

